\title{
Analys av allmänpreventionen med utgångspunkt från ekonomisk beslutsteori ${ }^{1}$ )
}

\author{
Av fil. lic. GÖRAN SKOGH, Lund
}

\section{Inledning.}

\subsection{Allmänprevention och individualprevention.}

Straffsanktioner motiveras i regel utifrån allmänpreventiva eller individualpreventiva argument.

Allmänpreventionen innefattar olika moment och kan uppdelas exempelvis enligt följande. ${ }^{2}$ ) Teorin om „omedelbar avskräckning" omfattar tanken att kombinationen av risk och straff avskräcker individen från att begå brottsliga handlingar. Teorin om „medelbar avskräckning" skiljer sig från den förra såtillvida att det snarare är strafflagens existens med hot om straff som utgör grunden till att individer avstår från brott. Det är däremot inte väsentligt hur straffet verkställs i det enskilda fallet, huvudsaken är att det på något sätt utkrävs för att hotet skall vara verksamt. Teorin om straffets "moralbildande verkan“ betonar lagstiftningens moraliska och inlärningsmässiga effekter. Lagens auktoritet påverkar människorna genom normbildning eller genom att stödja vissa normer.

Straffet har en "individualpreventiv verkan“ i den mån den aktuella individens benägenhet att begå brott i framtiden minska till följd av den påverkan individen utsätts för i samband med verkställd påföljd.

Någon mer systematisk specificering av den allmänpreventiva teorin har knappast förekommit. En sådan förefaller emellertid nödvändig för att man skall kunna bedöma straffrättsliga åtgärders effekt på brottsnivån. J. Andenæs har påpekat detta och även jämfört den allmänpreventiva effekten vid kriminella aborter och rattonykterhet och kommit till olika resultat vid de två brottstyperna. Bestraffning av illegala aborter tycks inte medföra någon minskning i deras antal. Däremot förefaller bestraff-

1) Denna uppsats utgör en omarbetad version av kapitel 7 i författarens licentiatavhandling (,Ekonomisk analys applicerad på straffrättsliga åtgärder". Nationalekonomiska institutionen vid Lunds universitet, maj 1972). Avhandlingen ingår som en delrapport i forskningsprojektet „,Resursallokering inom rättsväsendet“, vilket leds av författaren i samarbete med det svenska justitiedepartementets planerings- och budgeteringssekretariat. Finansieringen av projektet sker i huvudsak med medel från „Statens råd för Samhällsforskning“ i Sverige.

2) Se Elwin m. fl., Den första stenen, sid 55 ff., Malmö 1971, samt Törnudd, P., Om allmänpreventionen. Stencil. 
ning mot alkoholpåverkan i trafiken ha effekt, åtminstone i England då skärpt lagstiftning infördes år $1967^{3}$ ).

\subsection{Syfte och utgångspunkter.}

Det primära syftet med denna artikel är att skissera ett analysschema för sambandet mellan straff, risknivå och brottsmängd. Analysen kommer att ske utifrån ekonomisk beslutsteori. Det förefaller kanske egendomligt att ekonomisk teori kan vara användbar vid studiet av allmänpreventionen. Ett sekundärt syfte är därför att påvisa användbarheten av ekonomisk teori vid analys av straffrättsliga åtgärders effekt.

I ekonomisk mikroteori utgår man ofta från beslutsteoretiska modeller för individernas val i egenskap av konsumenter, producenter eller arbetskraft. Individernas beslut studeras vid alternativa kostnader och intäkter, men under förutsättningen att individernas normsystem är givet.

Likaväl som man kan förklara en arbetstagares val av arbete utifrån tillgången på försörjningsmöjligheter och alternativkostnader, bör man kunna förklara val av kriminella alternativ utifrån samma teoribildning. Brottsmängden blir då en funktion av det slumpmässigt fördelade priset (straffet) för brottshandlingen och kostnaden för andra alternativ samt intäkten av det kriminella alternativet och intäkter av andra alternativ.

En brottsling kan inte uppskatta utbyte och uppoffringar i penningbelopp annat än i undantagsfall, däremot kan man tänka sig att en individ väger förväntade uppoffringer mot förväntade utbyte och handlar för att maximera sin nytta, dvs. gemonför handlingen i det fall utbytet förväntas överstiga uppoffringen. Ett bötesbelopp kan betraktas som en mer eller mindre slumpmässigt fördelad kostnad. Frihetsberövande kan betraktas som en utvidgning av prissystemet då den monetära budgeten inte räcker till. Ett frihetsstraff innebär en inskränkning i individens tidsbudget. Den förväntade kostnaden att begå en kriminaliserad handling stiger rimligtvis vid höjning i risk och/eller straff. Detta kan väntas medföra färre brott.

Ett straffs moralbildande verkan består i en påverkan på individernas värdesystem. Detsamma gäller vissa individualpreventiva åtgärder, vilka påverkar individens normer. För studiet av dessa effekter kan knappast ekonomisk teori vara till hjälp.

Beträffande allmänpreventionens avskräckande moment förhåller det sig annorlunda. Avskräckningen förväntas påverka individernas beteende, även om moralkodex förblir oförändrat. Ändrat straff eller risk ändrar kostnadsupplevelsen oberoende

3) Andenæs, J. Om almenprevensjon og kriminalitetstype. Festskrift till Ivar Agge, 1970. 
om individens normer påverkas eller ej. Härigenom har vi också möjligheten att studera avskräckningen med hjälp av ekonomisk valhandlingsteori. Inom psykologien och sociologien förekommer också beslutmodeller av samma typ som används inom den ekonomiska beslutsteorin. ${ }^{4}$ ) Vi skall begränsa oss till en analys av straffets och riskens avskräckande effekt i samband med olika typer av brott och brottslingar. De moralbildande och inlärningsmässiga effekterna kommer vi i huvudsak att lämna åt sidan.

\section{Antaganden om potentiella brottslingars beteende.}

2.1. Potentiella brottslingar som nyttomaximerare.

Det är inte självklart att potentiella brottslingar är nyttomaximerare i den mening att de väger kostnader mot intäkter och handlar därefter. Invändningarna är av olika slag, t. ex. att brottslingen är ,orationell“ eller omedveten om den faktiska risken eller straffets storlek. Kriminalitet påstås ofta bero på faktorer som står utanför individernas kontroll. De „kriminella“ är impulsstyrda och inte långsiktiga nog att genomföra en kalkyl etc.

När man ifrågasatt brottslingars reaktion på straff, därför att dessa är ,orationella“, har man främst avsett något i likhet med „,oförnuftiga“ eller ,icke förutseende“. Vid användande av teoretiska beslutsmodeller måste vissa villkor om logisk rationalitet vara uppfyllda. Om en individ t. ex. föredrar ett tillstånd A framför ett annat tillstånd $\mathrm{B}$ och tillstånd $\mathrm{B}$ framför ett ytterligare tillstånd $\mathrm{C}$ så skall individen också föredraga A framför C. Det har knappast diskuterats huruvida brottslingar uppfyller detta villkor. Man kan antaga att det gäller i lika hög grad för dessa som för övriga. Om brottslingar kan antas vara kortsynta, besluta under osäkerhet eller vara impulsiva återkommer vi till längre fram. Det utesluter inte tillämpbarheten av en beslutsmodell. Det centrala är att individen i någon mening beaktar kostnader och intäkter och handlar därefter, dvs fattar ett beslut.

Straffbarhetsbegreppet bygger på förutsättningar om att brott är resultat av en viljehandling. Således är barn, psykiskt sjuka och så kallade jämställda undantagna från straffbarhet. Straffrätten förutsätter någon form av handling eller underlåtenhet från brottslingens sida. En väsentlig del av domstolens arbete består i fastställandet av handlingens uppsåt. En valhandlingsmodell för brottslingar för vilka straffen är tilllämpliga, ligger alltså inom ramen för den straffrättsliga doktrinen.

Vid analys av allmänpreventionen är man inte direkt intresserad av den enskilda individens beteende utan hur brottsnivån

4) Se t. ex. Homans, G. G., Social Behavior. Its Elementary Forms. London 1961. 
påverkas av straff och ertappningsrisk. Man behöver då heller inte förutsätta att varje individ strikt följer nödvändiga villkor för konsistenta beslut.

Eftersom olika grupper har olika värderingar och olika kostnader och intäkter, så kommer de att välja och reagera olika. På samma sätt kommer olika grupper av brottslingar att reagera olika på förändringar i risk och straff med olika effekt på brottsnivån beroende på vilken grupp som genomför brotten.

I t. ex. det fall brottsligheten beror på genetiska eller psykiska defekter, torde förändringar i risk eller straff knappast medföra förändringar i brottnivån. I de fall potentiella brottslingar är affärsdrivande, torde de reagera på kostnader och risker inom det straffrättsliga området, likaväl som inom andra områden, varför känsligheten i detta fall kan antas vara relativt betydelsefullt.

Vi är här intresserade av potentiella brottslingar, dvs. alla individer som vid förändringar i straff eller risk skulle kunna uppträda som brottslingar. När man diskuterat allmänpreventionen har man främst haft ett kriminellt belastat klientel i tankarna, dvs. redan straffade. Nedan skall vi finna att denna grupp förmodligen är tämligen okänslig för förändringar i straff och risk.

\subsection{Teorier om kriminalitet.}

Förekomsten av kriminalitet har förklarats på olika sätt. En förklaringsgrund baserar sig på en medicinsk-biologiskt eller psykologisk psykiatrisk uppfattning om den kriminelle som avvikande $\mathrm{i}$ något av dessa hänseenden ${ }^{5}$ ).

Under efterkrigstiden har dessa teorier kompletterats med sociologiska teorier om individernas relationer till omgivningen. Dessa inlärningsteorier baserar sig på den påverkan som individen utsätts för inom den samhällsgrupp där individen lever. Den kanske främste inlärningsteoretikern på området är Sutherland med sin teori om ,differential association"6).

Sutherland motsätter sig hypotesen om brottslighet som t. ex. ärftligt betingad och anser att kriminellt beteende är inlärt på samma sätt som annat beteende. Orsaken till att vissa människor begår brott är den inlärning de fått. Det förväntade utbytet och uppoffringarna eller intäkter och kostnader är beroende av individens preferensstruktur. Hur denna preferensstruktur utvecklas är en beteendevetenskaplig fråga och ligger som sådan utanför det ekonomiska området. Det förhållandet att olika individer genom gruppåverkan har olika värdering av kostnader och in-

5) Elwin m. fl. op. cit. sid 219.

6) Cressey, D. R., Delinquency, Crime and Differential Association. Hague, 1964. 
täkter motsäger inte antagandet om väljande individer utan förklarar varför individerna inte är homogena.

Sutherland har påpekat att tekniken för att begå olika brott kan vara mer eller mindre komplicerad. Detta är en anledning varför olika människor begår olika brott. „White collar crime“ begås till största del inom ,manschettyrkena“, medan kassaskåpssprängning begås av individer med kunskaper om sprängningens teknologi.

Inlärningen påverkar naturligtvis också möjligheterna att erhålla intäkter i form av legala alternativ. Lågt utbyte av legala alternativ ökar den brottsliga aktiviteten. Individernas kunskapsnivå påverkar också mängden beaktade alternativ.

Mertons anomiteori ${ }^{7}$ ) går i korthet ut på att kulturen uppställer vissa mål som är värda att eftersträva. Det finns också vissa accepterade medel att nå dessa mål. I den mån en individ upplever differensen mellan mål och möjligheter att uppnå detta med legala medel för stor, kan detta eventuellt lösas genom att tillgripa icke-accepterade medel, dvs. genom brott.

Cloward ${ }^{7}$ ) har byggt ut Mertons teori och framhävt att det inte är tillräckligt med legitima medel utan att det också måste föreligga illegitima möjligheter för att den brottsliga aktiviteten skall komma till stånd. Genom denna anmärkning är också sambandet med Sutherlands teori om ,differential assosiations“ klar. Kombinationen av möjligheter och ambitioner medför att vissa grupper av människor begår aktiviteter som är kriminaliserade.

Det har för kriminologerna varit ett problem att förklara den ökade broltsligheten i tillväxtekonomier. Här skall vi bara notera ett påpekande av Preben $\left.W_{\text {olf }}{ }^{\mathrm{s}}\right)$. Det faktum att tillgången på knappa varor stiger i en växande ekonomi kan synas medföra större behovstillfredsställelse med mindre brottsbenägenhet som följd. Wolf påpekar att i en växande ekonomi förekommer inte bara mer varor utan också fler tillfällen att stjäla. En allmän utökning av alternativen medför alltså i och för sig inte att de illegala lösningarna skulle bli färre. Den tekniska utvecklingen förenklar kriminella aktiviteter likaväl som legala. Wolf påpekar också inkomstfördelningsaspekten och strukturella problem i samband med en snabb ekonomisk tillväxt. Stora strukturella skillnader och social stratisfiering påverkar naturligtvis beteendet olika inom olika samhällsgrupper, med följd att vissa har „komperativa fördelar“ på den illegala „marknaden“.

7) Håkansson, K., De laglösa. Kriminalsociologiska studier. Orskarshamn 1969. Sid. $55 \mathrm{ff}$.

8) Wolf, P., Sociologisk teori og kriminologisk forskning. Festskrift til Stephan Hurwitz. Köpenhamn 1971, samt Crime and Development. An International Comparison of Crime Rates. Scandinavian Studies in Criminology. Vol. 3. 1971. 


\subsection{Antaganden beträffande brottsmängden.}

Vi har funnit att antagandet om beslutande potentiella brottslingar är i överensstämmelse med principerna för straffbarhet. Vi har också funnit att kostnadsöverväganden inte strider mot vedertagna kriminologiska teorier. Med dessa antaganden som grund skall vi införa fyra sekundära antaganden beträffande brottsmängdens beroende av olika faktorer.

A. Brottsmängden beror på intäkten i samband med brottet. Ju större intäkten är, ceteris paribus, desto större motivation finns för att genomföra det. Ju mer man förtjänar på brott, desto fler brott kommer att genomföras och vice versa.

B. Brottsmängden beror på intäkten av alla andra alternativ. En ökning i intäkten av andra alternativ medför att brott framstår som mindre attraktiva än i utgångsläget. Av denna anledning antar vi att brottsmängden går ner vid ökad intäkt av andra alternativ. Brottsmängden skulle i analogi med detta öka då intäkten av andra alternativ minskar. Med ,alla andra alternativ" avses de som beaktas i valsituationen.

C. Brottsmängden beror på kostnaderna att genomföra brottet.

Ju mer kostsamt det är att genomföra brottet desto fördelaktigare kommer andra alternativ (även brottsliga) att framstå. Kostnaderna att genomföra en brottslig handling utgörs av den resursåtgång som fordras för brottets genomförande inklusive förväntade kostnader i form av straff. Vid välplanerade kupper, smuggel, langning etc. kan den egna produktiva insatsen vara väsentlig, i annat fall torde förväntade kostnader för aktiviteten till övervägande del bestå i förväntade värden av straff. I den mån denna kostnad stiger kan man alltså utgå ifrån att brottsmängden minskar, ceteris paribus.

D. Brottsmängden beror på teknologiska betingelser.

Brottsmängden är beroende på produktionsförhållandena eller den teknologiska struktur som föreligger. Ökar de teknologiska möjligheterna att genomföra en kriminell aktivitet, kommer detta att öka aktiviteten. Tekniska förändringar har möjliggjort t. ex. butikssnatterier, vilka förutsätter självbetjäning, checkbedrägerier, som förutsätter checker, narkotikasmuggel, som förutsätter livliga internationella kommunikationer etc. Olika kunskaper medför att olika brottslingar använder olika teknologier (jämför Sutherland ovan).

Med utgångspunkt från dessa antaganden får vi att mängden av en viss brottstyp ökar 
när intäkterna av andra alternativ (legala eller illegala) minskar, när intäkterna av brottstypen ökar, när resursinsatsen för andra alternativ ökar, när resursinsatsen för brottstypen minskar, när straffets förväntade värde för brottstypen går ned, och när det förväntade straffet för andra brott ökar ${ }^{9}$ ).

9) Gjorda antaganden om sambanden mellan brott och alternativkostnader kan lätt formaliseras i matematiska termer t. ex. enligt följande:

I den ekonomi som studeras antar vi att det föreligger $\mathrm{r}$ olika alternativ.

$\mathrm{Q}_{\mathrm{k}}$ betecknar mängden av alternativ $\mathrm{k} . \mathrm{k}=1 \ldots \ldots \mathrm{r}$.

Av de olika alternativen är $\mathrm{k}=1 \ldots \ldots \mathrm{m}$ brottsliga, de övriga aktiviteterna $\mathrm{k}=\mathrm{m}+1 \ldots \mathrm{r}$ är lagliga.

Vi delar upp kostnaden $\mathrm{i}$ två komponenter. Ovan noterades att kostnaderna att begå brottsliga aktiviteter dels var avhängiga av resursinsatsen $\mathrm{i}$ aktivitetsögonblicket, vilket vi kan beteckna med $R_{k}$. En något artskild kostnad utgör det förväntade värdet av straff. Denna kostnad betecknar vi med $\breve{S}_{k}$. Vi introducerar tecknet för att poängtera att det gäller individens uppfattning. Även $R_{k}$ avser förväntat värde, men eftersom straffets eventualitet oftast är osäkrare har vi infört beteckningen här. Kostnaden att begå ett brott uppskattas alltsă till $\mathrm{K}=\mathrm{R}_{\mathrm{k}}+\breve{S}_{\mathrm{k}}$. Vid lagliga aktiviteter är naturligtvis väntevärdet av straff lika med noll. dvs. att

$\check{\mathrm{S}}_{\mathrm{k}}=0$ när $\mathrm{k}=\mathrm{m}+1 \ldots \mathrm{r}$

Intäkten av alternativ $\mathrm{k}$ skrives $\mathrm{I}_{\mathrm{k}}$.

Mängden brott av typen $\mathrm{k}=1 \ldots \ldots \mathrm{m}$ kan alltså skrivas $\mathrm{i}$ funktionsform enligt följande:

$\mathrm{Q}_{\mathrm{k}}=\mathrm{Q}_{\mathrm{k}}\left(\mathrm{I}_{\mathrm{l}} \ldots \mathrm{I}_{\mathrm{m}}, \mathrm{I}_{\mathrm{m}+\mathrm{l}} \ldots \mathrm{I}_{\mathrm{r}}, \mathrm{R}_{1} \ldots \mathrm{R}_{\mathrm{m}}<\mathrm{R}_{\mathrm{m}+\mathrm{l}} \ldots \mathrm{R}_{\mathrm{r}}\right.$,

$\check{\mathrm{S}}_{1} \ldots \ldots \check{\mathrm{S}}_{\mathrm{m}}$ )

Med utgångspunkt från de verbalt formulerade hypoteserna kan vi nu skriva att

$\frac{\partial \mathrm{Q}_{\mathrm{k}}}{\partial \mathrm{I}_{\mathrm{j}}}<0$ då $\mathrm{k}, \mathrm{j}=1 \ldots$ r och $\mathrm{k} \neq \mathrm{j}$

$\frac{\partial \mathrm{I}_{\mathrm{k}}}{\partial \mathrm{I}_{\mathrm{j}}}>0$ da $\mathrm{k}, \mathrm{j}=1 \ldots \mathrm{r}$ och $\mathrm{k}=\mathrm{j}$

$\frac{\partial Q_{k}}{\partial R_{j}}>0$ då $k, j=1 \ldots r$ och $k \neq j$

$\frac{\partial Q_{\mathrm{k}}}{\partial R_{\mathrm{j}}}<0$ då $\mathrm{k}, \mathrm{j}=1 \ldots \mathrm{r}$ och $\mathrm{k}=\mathrm{j}$

$\frac{\partial \mathrm{Q}_{\mathrm{k}}}{\partial \check{\mathrm{S}}_{\mathrm{j}}}>0$ då $\mathrm{k}=1 \ldots \mathrm{r}$ och $\mathrm{j}=1 \ldots$ m och $\mathrm{k} \neq \mathrm{j}$

$\frac{\partial \mathrm{Q}_{\mathrm{k}}}{\partial \check{S}_{\mathrm{j}}}<0$ då $\mathrm{k}, \mathrm{j}=1 \ldots \mathrm{m}$ och $\mathrm{k}=\mathrm{j}$ 
Vid t. ex. arbetslöshet minskar intäkterna av legalt arbete, varför brottsligheten kan väntas öka. Denna hypotes överensstämmer med bl. a. Fleishers resultat $\left.{ }^{10}\right)$. Ökade intäkter i samband med legal sysselsättning bör på motsvarande sätt minska brottsaktiviteten. Detta är ett argument som förekommer i en annan form, t. ex. vid inrättandet av ungdomsgårdar och liknande. Genom att skapa lagliga alternativ minskar det relativa utbytet av brottsliga alternativ.

När potentiella offer för brottslig verksamhet lägger ner större resurser för att skydda sina tillhörigheter så stiger den resursmängd som fordras för att genomföra den brottsliga aktiviteten, eventuellt stiger också förväntade värdet av straff. Detta bör alltså medföra en minskning i brottsaktiviteten. På samma sätt medför en minskad bevakning, t. ex. i form av självbetjäning, en tendens till ökad brottslig aktivitet.

En ökning i straff eller upptäktsrisk antas enligt avskräckningsteorin påverka det förväntade värdet av straffet. I den mån detta gäller så bör alltså en „medelbar“ eller ,omedelbar“ verkan föreligga. Enligt den moralbildande verkan skulle också värderingen av intäkten av den broltsliga aktiviteten minska med ökat straff, med ytterligare minskning i brottsnivån som följd. I den mån den straffade övar legala färdigheter under strafftiden kan intäkten av dessa stiga i framtiden, med avsedd individualpreventiv verkan, dvs. lägre brottslighet som följd. Övar sig däremot den intagne i illegala färdigheter så kommer intäkterna av dessa i framtiden att stiga och/eller nödiga resursinsatser att minska med en ökning i antalet brott som följd.

\section{Beaktade kostnader och faktiska värden på straff och risk.}

\subsection{Osäkerhetens betydelse.}

Den kostnad som potentiella brottslingar kan antas kalkylera med utgör en förväntad storhet och är som sådan beroende på både straff- och riskmoment. Större kostnader för brottet i fråga medför enligt antagande $\mathrm{C}$ ovan att antalet brott minskar. Om kostnaden, som individen beaktar, stiger när straff eller risk stiger så kan vi alltså vänta att antalet brott går ner. Detta antagande överensstämmer med uppfattningen om straffets och polisiära insatsers avskräckande verkan. Denna omständighet skall vi nedan kalla ,den enkla avskräckningsvarianten“.

Den enkla avskräckningsvarianten har attackerats från olika utgångspunkter. Iaktagelsen att antalet brott inte minskat vid ökat straffhot eller ökade polisiära insatser, har medfört att man ibland förkastat beslutsmodeller och avskräckningsmomentets giltighet för kriminella. Analysen har inte varit särskilt ingående.

10) Fleischer, B. M. The Effect of Unemployment on Juvenile Delinquincy. Journal of Political Economy 1963. Sid. $543 \mathrm{ff}$. 
Det är min uppfattning att beslutsmodellen och avskräckningstanken är en funktionsduglig teori i samband med analys av straffrättsliga åtgärder. Det fordras emellertid att analysen utvecklas utöver den enkla avskräckningsvarianten. Argument, som i vissa fall förts fram mot avskräckningsmomenten, skall nedan användas för att belysa användbarheten av en beslutsmodell där alternativval beaktas i enlighet med de antaganden som introducerats ovan.

Det behöver inte vara så att den förväntade kostnaden stiger när den faktiska risken eller det faktiska straffet stiger. Brottslingens beslutsfattande sker i regel under stor osäkerhet. Ett stort mått av osäkerhet torde också föreligga beträffande det faktiskt utdömda straffet. Straffets storlek beror på en rad olika omständigheter, t. ex. bevisföringen i rätten. Med undantag för de fall då straffen är i form av bötesbelopp, eller där viss enhetlig praxis utvecklats, torde det föreligga ett stort mått av osäkerhet om storleken på eventuellt straff. I den mån en brottsling ertappas ofta, under någorlunda likvärdiga omständigheter, så finns det möjligheter för denne att erfarenhetsmässigt skatta ertappningsrisken och straffet. Detta gäller kanske för systematiska felparkerare eller andra som med viss regelbundenhet betalar en avgift.

Brottslingar arbetar alltså under stor grad av osäkerhet. Hur dessa reagerar på förändringar i risk och utdömda straff beror på den strategi utifrån vilken de arbetar. Det finns olika teoretiska antaganden om olika strategier vid osäkerhet, ingen av dessa kan emellertid a priori anses vara mer trolig än andra ${ }^{11}$ ).

Summerar vi över många brottslingar och många brott kan man trots allt förmoda att väntade kostnader stiger när polisiära eller straffmässiga åtgärder ökar. Vi måste emellertid poängtera att det är brottslingarnas upplevelse av risk som är väsentlig, inte den faktiska. Som exempel på detta kan nämnas att trafikövervakning med patrullerande fordon anses effektivt minska trafikbrottens antal, detta trots att patrullerna inte sätter fast brottslingar. Det är i detta fall den skenbara riskhöjningen som är effektiv. Analogt kan man utgå ifrån att risk eller straffhöjande åtgärder, vilka är obekanta för potentiella brottslingar, saknar „medelbar" eller ,omedelbar“ verkan på brottsnivån.

\subsection{Tidsfaktorns betydelse.}

Ett eventuellt straff är placerat i framtiden i förhållande till beslutsögonblicket. Det medför förmodligen att det upplevs som lägre i handlingsögonblicket än sådant det utmäts i framtiden,

11) Thrall, Coombs m. fl. Decision Processes. New York 1957. Sid $255 \mathrm{ff}$. 
även om den aktuella individen har fullständig information om straffets storlek.

Ett av skälen till att sparare erhåller ränta på sina pengar är att man vill förmå denne att skjuta fram sin konsumtion. Hur mycket nutiden värderas i förhållande till framtiden beror naturligtvis på personen och omständigheterna kring valsituationen.

För att finna en analys om ,människans brist på tålamod“ och dess effekt på värdering av framtida kostnader kan vi gå tillbaka till Irving Fishers ränteteorier. Han har ställt upp en rad faktorer som antas bestämma individernas tidspreferenser. Som sådana bör de också gälla för potentiella brottslingar ${ }^{12}$ ).

Fisher lägger naturligt nog stor vikt vid inkomstens storlek och karaktär. Fisher antar att lägre inkomst medför att nutida inkomster värderas högre i förhållande till framtida intäkter. Detta antagande gäller framför allt mycket fattiga personer. För att man överhuvud skall överleva och erhålla någon inkomst $i$ framtiden fordras inkomster i nuläget. Ju knappare livsvillkoren är i nutiden desto mindre ser man också till framtiden, enligt Fisher, med åtföljande höga tidspreferens som följd.

Beträffande inkomstens fördelning över tiden antar Fisher att kostnader i framtiden värderas högre när man väntar sig en avtagande inkomstström än när inkomstströmmen förväntas förbli oförändrad eller stigande. Denna effekt torde vara speciellt betydelsefull vid låga inkomster.

Fisher tar också upp osäkerhel och risk i samband med kommande inkomstströmmar. Härvidlag är bilden mer oklar. I det fall man riskerar lägre inkomster i en framtid, t. ex. till följd av sjukdom eller arbetslöshet, kan det medföra att kostnader och intäkter i framtiden värderas högre. Är det däremot så att individen står inför en valsituation med en relativt säker inkomst i nuläget i förhållande till en osäker inkomst eller kostnad i framtiden, kan risken innebära en motsatt effekt på tidspreferensen.

Fisher tar också upp en rad personliga faktorer som han förmodar påverkar otåligheten eller tidspreferensen.

Ju större förutseende en individ har desto mindre otålig antar Fisher att människorna är. Ju mindre man reflekterar över framtiden desto större är tidspreferensen.

Självkontroll har effekter som motsvarar förutseendet. Med självkontroll avser Fisher viljestyrka, eller förmågan att styra sina impulser. Ju mer impulsiv, desto större tidspreferens eller brist på tålamod.

Vanan har också sin betydelse.

Den förväntade livslängd som en individ beaktar har som vi

12) Fisher, I. The Theory of Interest. Reprints of Economic Classics. New York 1970. Kapitel 4. Fisher hänvisar i sin tur till 1800-tals sociologen Cf. Rae och dennes „Sociological Theory of Capital“. 
tidigare sett betydelse för tidspreferensen. I den mån individen väntar sig en snar död så kommer tålamodet att minska. Kostnader i en framtid värderas lägre.

$\mathrm{Ju}$ större hänsyn individen tar till sina närstående, i den mån denne har sådana, desto lägre kan man anta att tidspreferensen blir. Om den egna förväntade livslängden är kort, men individen har anhöriga vars tillvaro han beaktar, så värderas kostnader i framtiden som högre.

Fisher tar slutligen upp yttre påverkan eller modeförhållanden. För brottslingar kan vi kanske överföra detta till inflytandet från omgivningen beträffande tidsvärderingen.

Fishers uppdelning av olika faktorer är i och för sig inte given, eller klar. Individernas egenskaper skulle kunna grupperas på annat sätt. Begrepp som ,självkontroll“ och ,för'utseende“ är inte klart definierade av Fisher. Det är också oklart huruvida Fisher skiljer på risk- och tidsfaktorn. Detta hindrar inte att det är intressant att se på de straffrättsliga implikationerna av Fishers ränteteori. Ränteteorin har till syfite att förklara räntans uppkomst. Det är emellertid påfallande hur väl Fishers punkter stämmer överens med gängse föreställningar om vad som konstituerar brottsligt beteende.

Då eventuellt straff är förlagt i framtiden är det upplevda straffet inte bara en funktion av straffets storlek i denna framtid utan nutidsvärderingen av detta. Dessa omständigheter ger enligt Fisher att ett straff upplevs som lägre när (1) inkomsten är låg, speciellt när den är nära existensminimum. (2) För individer med litet förutseende. (3) För individer med liten självkontroll eller impulsivitet. (4) För individer med kort förväntad livslängd. (5) För individer utan anhöriga eller då liten hänsyn tas till anhörigas liv och villkor. (6) För individer som av sin omgivning påverkas till hög tidspreferens eller otålighet. (7) När tiden mellan beslutsfattandet och straffets verkställighet är lång $\left.{ }^{13}\right)$.

13) Med utgångspunkt från det anförda kan vi utveckla de formaliserade hypoteserna $\mathrm{i}$ fornot 9 ovan med

$\check{\mathrm{S}}_{\mathrm{j}}^{\mathrm{i}}=\check{\mathrm{S}}_{\mathrm{j}}^{\mathrm{i}}\left(\mathrm{p}_{\mathrm{j}}^{\mathrm{i}}, \mathrm{S}_{\mathrm{j}}^{\mathrm{i}}, \mathrm{r}^{\mathrm{i}}, \mathrm{t}_{\mathrm{j}}^{\mathrm{i}}\right)$

där $\mathrm{j}=1 \ldots \ldots \mathrm{m}$ brottsliga aktiviteter och $\mathrm{i}$ betecknar individen.

$\mathrm{p}_{\mathrm{j}}^{\mathrm{i}}$ står för den faktiska risken för individ $\mathrm{i}$ att ertappas för den brottsliga handlingen $\mathrm{j}$ och

$\mathrm{S}_{\mathbf{j}}^{\mathrm{i}}$ är det straff som utmätes $\mathrm{i}$ det fall individen i ertappas.

$\check{S}_{\mathrm{j}}^{\mathrm{i}}$ betecknar som ovan kalkylarad kostnad i form av straff för brott $\mathrm{j}$ av individ $\mathrm{i}$.

$r^{i}$ står för individ i's tidsränta och

j står för tiden för individ i mellan brottet (j) och verkställan av eventuellt straff. 
4. Interdependensen mellan straffsatser.

4.1. Inkomst- och substitutionseffekten.

Osäkerheten medför att sambandet mellan straff och upplevt obehag är beroende av potentiella brottslingars information om eventuella risker och straff. Tidsfaktorn medför att straffets effekt minskar i den mån det är långt till straffets verkställan, speciellt när den potentielle brottslingens tidspreferens är stor. Dessa förhållanden motsäger inte den enkla avskräckningsvarianten utan reducerar enbart dess betydelse. I det kommande skall vi finna skäl som talar mot den enkla avskräckningsvarianten.

Individers utbud av aktiviteter (eller efterfrågan på varor) förklaras i pristeorin med hjälp av substitutions- och inkomsteffekten. Substitutionseffekten hänför sig till förändringar i relativa priser. Denna effekt verkar så att en kostnadshöjning medför ett minskat utbud. Detta gäller också brott. Substituerbarheten föreligger emellertid också mellan olika brottsalternativ.

Om straffet eller risken för en brottstyp höjs så behöver det inte innebära att antalet brott går ner. Antalet andra brott kan stiga i sådan omfattning att de väger upp minskningen i den brottstyp för vilken höjningen införes. Detta gäller speciellt när de aktuella brottslingarna har relativt litet utbyte av legala alternativ. I detta fall är substituerbarheten mellan olika brott stor, men substituerbarheten mellan lagliga och olagliga alternativ är liten.

Som exempel på detta fenomen kan nämnas begränsningar i användandet av checksystemet i Sverige, vilket i detta sammanhang innebär att kostnaderna för att genomföra checkbedrägerier gått upp. I samband med detta har antalet postbedrägerier och inbrott stigit kraftigt, vilket kan bero på förändringarna i bruket av checkar, speciellt som många brottslingar är narkomaner utan legala möjligheter att erhålla sin narkotika ${ }^{14}$ ).

En prisförändring medför en förändring i realinkomsten. Denna effekt benämnes inom pristeorin för inkomsteffekten. I den mån kostnader utgör en liten del av individens budget kan man i vissa fall bortse från denna effekt. Vid påföljder motsva-

Idén om „omedelbar“ eller „medelbar“ verkan förutsätter implicit att

$$
\frac{\partial \dot{S}_{j}^{i}}{\partial \mathbf{S}_{j}^{i}}>0, \frac{\partial \check{S}_{j}^{i}}{\partial \mathbf{p}_{j}^{i}}<0
$$

Förekomst av en tidspreferens medför att

$$
\frac{\partial \check{\mathrm{S}}_{\mathbf{j}}^{\mathrm{i}}}{\partial \mathbf{r}^{i}}<0 \text { och } \frac{\partial \check{\mathrm{S}}_{\mathrm{j}}^{\mathrm{i}}}{\partial \mathrm{t}_{\mathrm{j}}^{\mathrm{i}}}<0
$$

14) Rikspolisstyrelsen. Petita 1972/73. Stockholm 1972. 
ras detta av böter till små belopp. I regel kan man emellertid inte bortse från inkomsteffekten vid straff av olika slag, enär dessa påtagligt förändrar individens levnadsvillkor. Vid straff föreligger det speciella förhållandet att inkomsteffekten enbart gäller för dem som faktiskt straffas. Blir man inte straffad så får straffet ingen effekt på inkomstnivån, substitutionseffekten verkar däremot genom den förväntade kostnaden.

\subsection{Brottkonkurrens och stordriftsfördelar.}

Vid brottkonkurrens, dvs. att flera brott behandlas samtidigt, dömes i princip med utgångspunkt från det allvarligaste brottet. Orsaken till detta kan vara att man i domstolen koncentrerar intresset på uppsåtet. Man blir straffad för att man visat sig vara istånd till brottet ifråga, då är man ganska naturligt istånd till att begå ett brott till. Det mindre eller jämställda additativa brottet tilldelas därvid relativt lite avseende.

En annan orsak till att additativa brott inte straffas lika mycket som det första kan bero på inkomsteffekten av det första straffet. Det går inte att döma ut hur många eller stränga straff som helst. Individens tidsbudget räcker inte till, frihetsberövandet kan inte utsträckas hur långt som helst. Samtidigt föreligger det en rad restriktioner beträffande strafformer enär tortyr, stympning, gatlopp, dödsstraff etc. inte längre tillåtes.

Detta medför en speciell form av stordriftsfördelar vid brottslig verksamhet. En brottsling uppskattar rimligtvis straffet som lägre för brotten $1 . \ldots \mathrm{m}$-1, under förutsättning att denna ertappas för brott m. Införes t. ex. livstidsstraff vid rån i likhet med straffet för mord, så är det lika bra att mörda rånoffret om det väntas medföra någon fördel. Det marginella straffet för mord är i detta fall lika med noll.

I den mån individerna inte överger det första brottsalternativet så kommer en risk- eller straffhöjning att upplevas som en straffminskning för additativa brott. Detta innebär i sin tur en tendens till ökning i brottsvolymen för dem som inte undviker att begå brottet $\mathrm{i}$ och med höjningen. För att avgöra huruvida brottslingarna övergår till andra aktiviteter vid en höjning får man bedöma deras tillgång på alternativ, lagliga såväl som illegala.

Av detta resonemang kan vi också dra en annan slutsats. Höga sanktioner medför fördelar att begå många brott i förhållande till få. De som trots höga sanktioner begår brott, genomför därför förmodligen många brott, alternativet är att helt avstå från brottslig verksamhet. Höga straffsatser och intensiva polisinsatser tenderar alltså att polarisera befolkningen i grupper av „laglydiga“ och „kriminella“. Denna tendens förstärks vid upprepade påföljder, vilket vi skall studera i nästa avsnitt. 


\subsection{Brottsmängdens beroende av tidigare straff.}

Det är uppenbart att ju färre tillgångar en individ har desto mindre kan man beröva från denne. Detta gäller också för brottslingar. Ju fler gånger en individ straffas, desto mindre kan man beröva vid ytterligare straff, såvida individen inte rehabiliterat sina tillgångar mellan strafftillfällena. Detta kommer att innebära att ju strängare och ju oftare en person dömes, desto snabbare kommer individen till den nivå där samhället lägger restriktioner för ytterligare bestraffning.

Detta är en långsiktig effekt av straff. Nedan skall vi studera denna effekt med hjälp av ett mycket förenklat matematiskt exempel. Vi betecknar antalet tillfällen en individ har varit straffad med $t$. $t$ kan antas växa mel ökad risk. Vi antar vidare att hela inkomsten är kvantifierbar. Den totala tillgången består av till nuvärde diskonterade inkomster. Tillgången betecknas med $Y_{t}$ vid $t^{\prime}$ te strafftillfället. $t=0,1 \ldots \infty$.

Vi antar vidare att det föreligger en restriktion beträffande lägsta tillåtna värde på tillgångarna, detta värde betecknas $Y_{\min }$, och motsvaras av existensminimum eller den allmänna nivå under vilken standard en individ $\mathrm{i}$ samhället inte anses skall sjunka.

Straffet som genomförs består i att en del av inkomsten berövas innehavaren. Inkomsten tillåts inte sjunkt under $\mathrm{Y}_{\min }$. Straffets storlek kan vi uttrycka med formeln:

$$
\mathrm{S}_{\mathrm{t}}=\mathrm{s}_{\mathrm{t}}\left(\mathrm{Y}_{\mathrm{t}}-\mathrm{Y}_{\min }\right)
$$

där $S_{t}$ står för straffet vid t'te strafftillfället och $s_{t}$ anger den kvot, som berövas individen av tillgångarna som överstiger den minsta tillåtna. $0 \leq \mathrm{s}_{\mathrm{t}} \leq 1$.

Om vi antar att $s_{t}=s$ är en konstant och lika för $t=0,1$ $\ldots \ldots \infty$, samt att $\mathrm{Y}_{\mathrm{t}}=\mathrm{Y}_{\mathrm{t}-\mathrm{l}}-\mathrm{S}_{\mathrm{t}-1}$, dvs. att tillgångarna inte rehabiliteras mellan strafftillfällena, så kan uttrycket $/ 9 /$ förenklas till $\mathrm{S}_{\mathrm{t}}=\mathrm{s}(1-\mathrm{s}) \mathrm{t}\left(\mathrm{Y}_{\mathrm{o}}-\mathrm{Y}_{\min }\right) \quad / 10 /$.

$Y_{0}$ står för den initiala inkomsten.

Av detta kan vi dra vissa slutsatser. För det första ser vi att ju större krav som ställs i samhället på lägsta standard $\left(Y_{\min }\right)$ desto lägre blir genomgående straffen. För det andra ser vi att ju större den initiala inkomsten är desto större straff är det möjligt att utdöma. I den mån den straîfade rehabiliterar sina tillgångar finns det också större möjligheter att utdöma straff i framtiden.

Intressantare är emellertid att ju större straff vid första tillfället, vilket innebär att $s$ är stor, desto mindre är (1-s), vilket i sin tur medför att $(\mathrm{l}-\mathrm{s})^{\mathrm{t}}$ går snabbare mot noll. Detta innebär att ju strängare straff man tillämpar vid första tillfället desto mindre möjligheter har man att straffa vid nästa tillfälle. 
En straffhöjning medför på lång sikt att den som straffas kommer att ha lägre kostnader i framtiden att begå brott än ostraffade.

I realiteten är naturligtvis inte $s_{t}$ konstant. Ofta utdömes relativt lindriga domar vid första strafftillfället medan de senare skärps. Även lindriga straff kan ha avsevärd effekt på framtida inkomster genom försämrade möjligheter på arbetsmarknaden. I verkligheten kan straffade rehabilitera sina inkomster mellan strafftillfällena, vilket vi bortsett från ovan. Rehabiliteringsmöjligheterna torde emellertid inte vara alltför stora med utgångspunkt från arbetsmarknadssituationen och den skuldsättning som ofta förekommer hos straffade.

Trots avvikelser från modellen torde dess huvudsakliga implikationer gälla. En höjd straffsats må ha en kortsiktigt brottsminskande effekt genom att vissa avstår från att begå brottet ifråga. Av dem som ändå begår brottet och straffas kommer straffökningen att ha en brottshö jande effekt, därför att straffade relativt sett kommer att ha mindre kostnader i form av straff än ostraffade. Höga straff förefaller alltså även på lång sikt medföra en polarisering till grupper av "laglydiga“ och ,kriminella“ i samhället.

\section{Sammanfattande synpunkter.}

5.1. Analysschema vid risk-eller straffändringar.

Huvudsyftet med denna artikel är att formulera ett analysschema för straffrättsliga åtgärders effekt på brottsmängden. Vi har nu kommit så långt att detta låter sig göras. Analysen kan lämpligen uppdelas i ett antal moment enligt följande.

A. Fastställande av populationen potentiella brottslingar.

Med potentiella brottslingar avses de individer, vilka kan tänkas påverkas av den aktuella åtgärden. Eftersom det är ovisst vilka som begår de aktuella brotten kan det föreligga svårigheter att fastställa brottslingspopulationen. Det är emellertid inte omöjligt att i grova drag ringa in denna. Skattebrott begås t. ex. av skattepliktiga, bilförare begår trafikbrott, havande kvinnor låter genomföra illegala aborter etc. Man kan naturligtvis också utföra intervjuundersökningar för att ta reda på vilka typer av brott som begås av olika individer. En sådan har genomförts för skolbarn i Sverige. ${ }^{15}$ ) I vissa fall kan man naturligtvis utgå från redan straffade personer. Detta förutsätter emellertid att de ertappade ger en tillräckligt god bild av populationen. Vissa brott, t. ex. grova tillgreppsbrott, begås i stor utsträckning av tidigare straffade.

15) Elmhorn, K., Faktisk brottslighet bland skolbarn. SOU 1971: 74. Stockholm 1971. 
B. Bedömning av brottslingarnas alternativa möjligheter.

I det ovanstående har vi funnit att alternativmängderna påverkar substitutionsmöjligheterna. Har populationen god tillgång till legala alternativ kan vi vänta att man i viss utsträckning övergår till dessa. Har man god tillgång till andra illegala alternativ så kan man förmoda att individerna övergår till dessa. Har individerna ont om eller inga alternativ, så kommer de inte att reagera för den aktuella ökningen.

\section{Kostnader för legala och illegala alternativ.}

Det krävs en bedömning av uppoffringar för olika alternativ. I detta sammanhang är det intressant att studera hur stor andel förväntat straff utgör. För vissa individer torde själva ertappandet med följande prestigeförlust vara tungt vägande, varför marginella förändringar i straffsats kan vara negligerbara.

D. Osäkerhetsgraden i brottslingens valsituation.

Brottslingens föreställning om straff och risk är avgörande, inte de faktiska förhållandena. Många förändringar i straffrättsliga eller polisiära åtgärder når förmodligen inte fram till förövaren före ertappandet, varför ătgärderna är verkningslösa.

\section{E. Tidsfaktorn.}

Tiden mellan brott och eventuellt straff kan vara av väsentlig betydelse, speciellt om brotten förövas av impulsiva, kortsynta, eller fattiga personer. Dessa kan förväntas ha en hög tidsränta. Består brottslingarna av planerande individer med pengar på banken och höga inkomster, så kan man förmoda att tidsräntan är låg, varför tidsfaktorn har mindre betydelse i detta fall. Vid t. ex. skattebrott kommer intäkten till och med ofta efter eventuell opptäckt av brottet (falskdeklaration medför intäkter först ett år senare). Tidsräntan är i detta fall förmodligen låg, eftersom även kommande intäkter skall diskonteras till nuvärde.

\section{F. Kombinationer av brott.}

Ovan framkom att kostnaderna för det marginella brottet är beroende av straffet för det allvarligaste brottet bland dem som upptäcks. En straffhöjning eller riskhöjning kan medföra att additativa brott betingar lägre kostnader med åtföljande tendens till fler brott.

\section{G. Upprepade påföljder.}

Utdömt straff kommer att ha mindre effekt ju fler gånger individen varit straffad tidigare. En straff- eller riskhöjning för 
ett redan belastat klientel tenderar att isolera dessa ytterligare från övriga samhällsmedborgare.

H. Moral och individualpreventiva effekter.

Analysen har i huvudsak berört avskräckningseffekterna. I den măn åtgärderna påverkar moralen, t. ex. genom att värderingen av intäkterna blir mindre, så kommer det att ha en brottsminskande effekt. Om den studerade åtgärden innefattar vård, som påverkar den behandlade individens preferenser för illegala och legala handlingar, så skall detta naturligtvis beaktas. Denna del ligger emellertid utanför en ekonomisk analys. Det är av vikt att erinra om att den ekonomiska analysen enbart är en del av den totalbedömning som måste göras beträffande åtgärdens effekt på brottsmängden.

\subsection{Utvecklingsmöjligheter.}

Vid böter är inkomsteffekterna relativt små. Detta gör att bötesstraff förefaller relativt effektiva. Samhällskostnaderna i samband med böter är små, eftersom bötesbeloppen är en form av transfereringar. Böter förutsätter att de straffade har möjlighet att betala dessa. Böter tillämpas också för relativt små förseelser, eller förseelser som ofta upptäcks och som begås av individer med fasta inkomster och därmed relativt långsiktig planering. I dessa fall kan man utgå ifrån att straffen och riskmomentet har en väsentligt minskande effekt på brottsnivån $\left.{ }^{16}\right)$.

Vid frihetsberövande och andra samhällsingripanden är bilden mer komplicerad. Sammanfattningsvis kan man säga att i de fall brottslingarna beaktar få alternativ till den illegala verksamheten, t. ex. har små möjligheter på arbetsmarknaden, eller har trängande behov av t. ex. narkotika och/eller har kort tidsperspektiv, är tidigare straffade etc., så medför straff eller riskhöjningar knappast minskad brottsnivå. Det är också möjligt att antalet brott stiger.

Straffens nedbrytande och segregerande effekt har framförts på olika sätt i den kriminalpolitiska debatten. Dessa argument stöds av den valhandlingsmodell som presenterats ovan. Det kan vara fullt rationellt att begå brott, inte minst om man tidigare varit straffad. I den mån höga straffsatser avskräcker från brott så torde det gälla „laglydiga“ eller tidigare ostraffade individer. Återfallsförbrytaren får härigenom den samhällsbevarande, men ack så otacksamma, funktionen att avhålla andra från brott. ${ }^{17}$ )

16) Se Bratholm, A., Bør adgangen til å anvende bøtestraff utvides? Lov og Rett nr. 51967.

17) Se Eckhoff, T., Samhället får den kriminalitet det förtjänar. Ingår i „I stället för fängelse“, red. av. Nestius, H., Oskarshamn 1970. 
Kritiken mot strängare frihetsstraff har kombinerats med förslag om alternativ. Beteendevetare har t. ex. föreslagit inlärningsmässiga insatser. Genom t. ex. gruppterapi vill man påverka individens referensram och attityder. Även om man avstår från att påverka individernas preferenssystem föreligger det en rad möjligheter. Genom arbetsmarknadspolitiska åtgärder av olika slag kan t. ex. legala inkomstalternativ skapas. Genom legala sysselsättningsalternativ, t. ex. fritidslokaler för ungdomar, tenderar brottsmängden att minska. Genom utbildning kan analoga effekter erhållas etc.

Den potentielle brottslingens beslutssituation kan påverkas på två principiellt skilda sätt. Genom att förändra mängden alternativ och kostnaderna för dessa kan individens val påverkas utan att man i princip behöver påverka dennes värdesystem och normer. På motsvarande sätt kan man påverka individens värderingar och attityder beträffande den brottsliga handlingen utan att för den skull förändra kostnadsstrukturen för olika alternativ. Individualpreventiva åtgärder kan sålunda resultera i förändringar i kostnader och intäkter för individen. Andra åtgärder förändrar inte de alternativa möjligheterna, men däremot värderingen av de olika alternativen. Någon distinktion mellan behandlingsformer som syftar till att påverka det alternativa utbytet kontra preferensstrukturen föreligger knappast explicit.

Det har genomförts relativt många undersökningar om fängelsestraffets effekt. En del utredningar är rent deskriptiva $\left.{ }^{18}\right)$, i andra har man uppmätt återfallsrisker med utgångspunkt från olika individuella karaktäristika och strafformer $\left.{ }^{19}\right)$. Det saknas en enhetlig teori om sambanden mellan de olika variablerna. Det här angivna beslutsteoretiska angreppssättet kan tjänstgöra som utgångspunkt. Uppmätta faktorer som anställning, yrke, antal straff, anstaltsvistelser, hälsotillstånd, beroende av stimulantia, familjebakgrund, anpassning etc. kan kategoriseras med utgångspunkt från hypoteser om kalkylerade intäkter, kostnader och alternativ. De resultat som erhållits beträffande anstaltsklientelet och återfallsfrekvenser stödjer i stort de antaganden som gjorts i denna artikel $\left.{ }^{20}\right)$. Den beslutsteoretiska utgångspunkten överensstämmer också med principerna för straffbarhet och vedertagna kriminologiska teorier om kriminalitetens orsaker.

Göran Skogh.

1s) Se Kriminalvård i anstalt. SOU 1971: 74. Sid 328 ff.

19) Börjesson, B., Om påföljders verkningar. Stockholm 1966.

20) Glaser, D., The Effectiveness of a Prison and Parole System. New York 1964. Sid. $504 \mathrm{f}$. 